UDC 316.353:2

LBC 60.545.4

\title{
TOLERANCE AS A VALUE IN THE SOCIO-CULTURAL LANDSCAPE OF THE REGION ${ }^{1}$
}

\author{
Ekaterina O. Belikova \\ Volgograd State University, Volgograd, Russian Federation
}

\begin{abstract}
The paper analyzes Russian and foreign experience in studying the problems of interethnic and interreligious tolerance. Special attention is paid to the essence of the sociological approach to the concept of "tolerance". Different approaches to this term by domestic and foreign scientists make it possible to determine the multidimensionality of this concept and differentiate it by the problem principle, highlighting the social, interethnic, interreligious, gender, cultural components, which are associated with political, ethnic and cultural spheres of social interaction. The author focuses on the need for an interdisciplinary approach to the study of interethnic and interreligious tolerance, involving the coordinated application of modern methods of sociology, social psychology and philosophy. The article deals with interethnic and interreligious tolerance as a social value, which serves as a strategy of interaction in a multicultural region (on the example of the Volgograd region). This strategy can not only prevent the development of conflicts on ethno-religious basis, but also become a consolidating idea of interaction of different social communities. The article also analyzes the results of the study of the level of tolerance in the Volgograd region within the framework of the scientific project of 2019 "Preservation and transmission of regional values as a condition of modernization of the sociocultural landscape of the modern Russian region", which is devoted to the study of different aspects of life of the Volgograd region residents. The standard method "Sociocultural landscape of the region", developed by a group of sociologists of Volgograd State University under the guidance of the author of the article, was used as the fundamental one. Based on the data from the formalized interview with residents of the region, the specifics of the Volgograd region as an integral sociocultural landscape in the context of the sociocultural space of Russia are analyzed. Special attention in the study is paid to the level of tolerance of the population to representatives of other nationalities and religions. The author concludes that joint conflict-free and tolerant attitude towards each other can become a new value in the region under study.
\end{abstract}

Key words: sociocultural landscape, tolerance, interethnic interaction, tolerance, worth.

УДК 316.353:2

ББК 60.545 .4

\section{ТОЛЕРАНТНОСТЬ КАК ЦЕННОСТЬ В СОЦИОКУЛЬТУРНОМ ЛАНДШАФТЕ РЕГИОНА ${ }^{1}$}

\author{
Екатерина Олеговна Беликова \\ Волгоградский государственный университет, г. Волгоград, Российская Федерация
}

\begin{abstract}
Аннотация. В работе анализируется российский и зарубежный опыт исследования проблем межэтнической и межрелигиозной толерантности. Особое внимание уделено сущности социологического подхода к понятию «толерантность». Различные определения данного термина отечественных и зарубежных ученых позволяют раскрыть его многомерность и дифференцировать по проблемному принципу, выделяя социальную, межэтническую, межрелигиозную, гендерную, культурную составляющие, которые связаны с пол литическими, этническими, культурными сферами социального взаимодействия. В статье рассматривается м межэтническая и межрелигиозная толерантность как социальная ценность, которая выступает в качестве \% только препятствовать развитию конфликтов на этнорелигиозной почве, но и стать консолидирующей идеей взаимодействия различных социальных общностей. В статье также проанализированы результаты исследования уровня толерантности населения в Волгоградской области в рамках научного проекта 2019 г. «Сохране-
\end{abstract}


ние и трансляция региональных ценностей как условие модернизации социокультурного ландшафта современного российского региона», который посвящен исследованию различных сторон жизни жителей Волгоградской области. При проведении исследования была использована типовая методика, разработанная группой социологов Волгоградского государственного университета при руководстве автора статьи (в ходе выполнения работы по гранту РФФИ № 18-411-340011 p_a). На основе данных проведенного с жителями региона формализованного интервью анализируется специфика Волгоградской области как уникального социокультурного ландшафта, включенного в социокультурное пространство России. Особое внимание в исследовании уделено вопросам уровня толерантности населения к представителям других культур. Автор делает выводы о том, что совместное бесконфликтное и толерантное отношение друг к другу может стать новой ценностью в изучаемом регионе.

Ключевые слова: социокультурный ландшафт, толерантность, межнациональное взаимодействие, терпимость, ценность.

\section{Введение}

В современном социокультурном пространстве регулярно возникают конфликты на национальной почве, которые негативно влияют на геополитическую обстановку в самых различных регионах мира. Наряду с этим проявляются и проблемы поколений и социальных слоев, зачастую имеющих диаметрально противоположные ценностные установки. Сегодня сообщество, находясь перед лицом социальных противоречий, ищет пути межэтнического, межрелигиозного и межкультурного взаимопонимания и совместного существования. В современной России, особенно в трансграничных регионах, наблюдается расширение миграционных потоков, которые привели к развитию мультикультурности. Общество столкнулось с необходимостью поиска стратегии взаимодействия с представителями «инокультур» в русле комфортного, бесконфликтного сосуществования - «стратегии толерантности».

В настоящее время понятие «толерантность» часто используется в различных сфеpax, иногда теряя свое первостепенное значение. Социологическое понимание уходит своими корнями в эпоху Просвещения. В трудах философов С. Кастеллио, П. Бейля, Дж. Локка толерантность провозглашается главной ценностью гражданского общества [Локк 1988]. В настоящее время трактовка этого термина расширена и затрагивает целый ряд политических, социальных вопросов.

В философском понимании «толерантность» - терпимость к иного рода взглядам, нравам, привычкам. Толерантность необходима по отношению к особенностям различных народов, наций и религий. Она является при- знаком уверенности в себе и сознания надежности своих собственных позиций, признаком открытого для всех идейного течения, которое не боится сравнения с другими точками зрения и не избегает духовной конкуренции [Васильева (ред.) 2011]. В социологическом же аспекте под термином «толерантность» подразумевается терпимость к иному мировоззрению, образу жизни, поведению и обычаям. В рамках социологической методологии исследования толерантности основное внимание уделяется системе ценностей, входящих в структуру социального сознания, влиянию толерантных или интолерантных ценностей, норм и образцов поведения на установки и поведение отдельных индивидов или групп, системе межгрупповых взаимодействий (межнациональных, межэтнических и т. д.) [Кустова, Меркулов, Арабаджийски 2018]. Такая система ценностей, как часть стратегии сосуществования в мультикультурном обществе, может быть насаждаема сверху, например, властями, а может быть исторически отработана в конкретном регионе, в качестве которого в нашем исследовании выступает Волгоградская область.

В Волгоградском регионе проблема взаимоотношений людей разных национальностей, вероисповеданий, убеждений, социального положения и возраста, разного культурного опыта исторически обусловлена многими факторами [Беликова 2016]. Усиливающиеся в последнее время миграционные процессы, объективно расширяющиеся межконфессиональные и межкультурные связи неизбежно приводят к возникновению новых социальных, политических, экономических, образовательных и прочих проблем. 


\section{Теоретические подходы и опыт эмпирических исследований толерантности}

Среди теоретических социологических оснований, которые используются для объяснения межэтнической и межрелигиозной толерантности в различных социумах, а также их диахронных изменений, наибольшим эвристическим потенциалом обладают теория ценностей, теория социокультурного ландшафта, теория этничности и национализма.

В российских исследованиях социокультурный контекст толерантности заключается в возможности формирования толерантных установок, в том, что толерантность является социокультурной основой ненасилия, так как реализует различные предпосылки для выработки новых форм взаимодействия с «другими» людьми - общение в Интернете, межконфессиональные проекты и др. [Неровная 2018]. Мультикультурализм обеспечивается стремлением к межкультурному диалогу, который связан с различными формами самовыражения и способами проявления человеческой индивидуальности. Толерантность является форматом предупреждения конфронтационных процессов, формирования межличностных отношений в духе терпимости, ненасилия, уважения, солидарности и др. [Зиннатова 2017]. Вопросы социального взаимодействия в обществе представлены в работах А. Бергсона, П. Бурдье, Ч. Кули, П. Сорокина, Ю. Хабермаса, П. Штомпки и др.

Западными социологами проводятся исследования вопросов толерантности в различных ее проявлениях. В аспекте миграционных проблем толерантность исследуется М. Амбросини, А. Мак Маон, М. Купишжевским [Kupiszewski 2013]. В контексте религиозной проблематики, в частности, взаимоотношений христианства и ислама - П. Крюйнигером [Kruiniger 2015]. В контексте этнической проблематики интересны работы Р. Гержака, С. Хавы, М. Муашера, 3. Булутжила [Hawa 2017].

Среди социологических исследований толерантности на региональном уровне можно выделить монографию Н.М. Лебедева, Т.В. Таболина, Ю.А. Гаюрова «Этническая толерантность в поликультурных регионах России», в которой приводятся результаты эм- пирических исследований толерантности, кросс-культурное сопоставление стратегий межгруппового взаимодействия разных этнических и конфессиональных групп в зависимости от особенностей их этнической идентичности и уникальной региональной ситуации [Лебедева, Таболина, Гаюрова 2002].

Исследования уровня толерантности в конкретных регионах проведены российскими социологами С.В. Рыжовой , О.А. Богатовой, А.И. Карьгиным, Г.У. Солдатовой, Е.И. Шлягиной [Рыжова 2016; Богатова, Карьгин 2010]. Подробный обзор прикладных и теоретических исследований межнациональных и межрелигиозных отношений в пограничных регионах РФ представлен в работе А.С. Качур [Качур 2019].

В своем исследовании автором была предпринята попытка изучения толерантности как стратегии межнационального и межкультурного взаимодействия в спектре социокультурного ландшафта региона.

\section{Методика \\ социологического исследования}

В основе методики изучения социокультурного ландшафта Волгоградской области лежит социокультурный подход, разработанный доктором философских наук Н.И. Лапиным [Лапин 2009]. Особый акцент в работе сделан на полиэтничность и поликонфессиональность социокультурного ландшафта региона. Исследование проходило в рамках научного проекта «Сохранение и трансляция региональных ценностей как условие модернизации социокультурного ландшафта современного российского региона», который посвящен исследованию различных сторон жизни жителей Волгоградской области. Эмпирической базой проекта послужил материал социологического исследования (массовый опрос), проведенный в регионе в 2019 г. посредством метода формализованного интервью в 10 населенных пунктах Волгоградской области по квотной выборке, репрезентированной по полу и возрасту, случайной на этапе отбора респондентов. Репрезентативность выборки обеспечивается соблюдением пропорций между населением, проживающим в населенных пунктах различных типов (районы города и сельс- 


\section{СОЦИОЛОГИЯ И СОЦИАЛЬНЫЕ ТЕХНОЛОГИИ}

кие населенные пункты), половозрастной структуры взрослого населения Волгоградской области. Объем выборки составил 1200 человек. Полученные данные обрабатывались с помощью пакета прикладных программ SPSS.

\section{Результаты исследования}

Одной из задач массового опроса стало выявление отношения респондентов к представителям других национальностей и миграции в Волгоградской области.

Респонденты склонны оценивать состояние межнациональных отношений в Волгоградской области, скорее, как нейтральное 44 \%. Немаловажно, что $39 \%$ считают межнациональные отношения в области благоприятными, в то время как только $10 \%$ склонны утверждать обратное, указывая на неблагоприятность, возможность конфликтов (рис. 1).

Более половины опрошенных жителей уверены, что обстановка в сфере межнациональных отношений в Волгоградской области за последние 3 года никак не изменилась (57\%). На ее улучшение указывают $19 \%$ респондентов. И только каждый седьмой опрошенный склонен говорить о том, что обстановка в сфере межнациональных отношений ухудшилась (15\%) (рис. 2).

Обсуждая проблемы, которые, на взгляд респондентов, являются основными, возникающими в сфере межнациональных отношений в области, большинство опрошенных называет безработицу, незанятость населения $(21,8$ \%). Также к проблемам участники опроса зачастую относят различия в религиозных взглядах $(14,2 \%)$ и культурные $(12,5 \%)$ (см. рис. 3).

Опрошенные в г. Волгоград (19,2\%) чаще всего к проблемам, возникающим в сфере межнациональных отношений в Волгоградской области, относят агрессивность, вызывающее поведение отдельных групп и лиц, а также безработицу, незанятость населения.

По мнению респондентов, наиболее актуальными проблемами в этнической сфере являются большие миграционные потоки из стран ближнего зарубежья и других регионов России (27,2 \%), отток населения (18,9\%) и утрата культурной самобытности $(18,1 \%)$. Ассимиляция народов стала наименее выби-

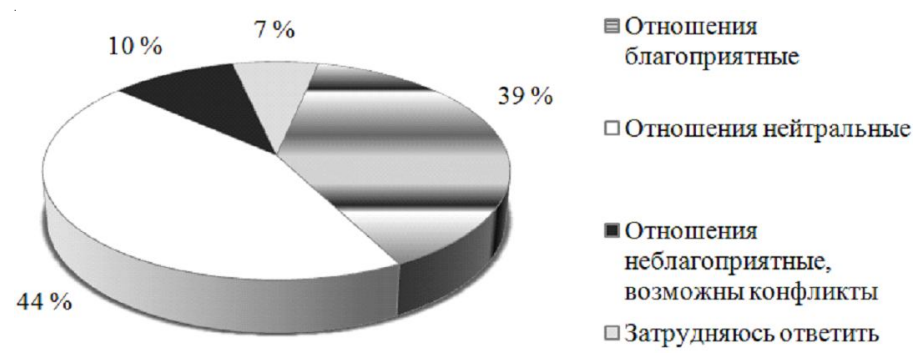

Рис. 1. Оценка межнациональных отношений

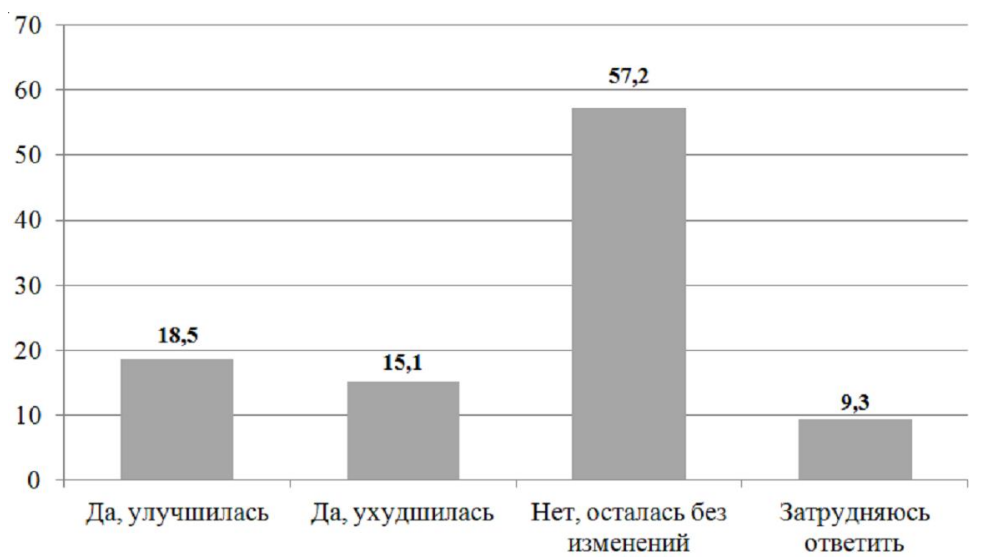

Рис. 2. Изменение обстановки в сфере межнациональных отношений за последние 3 года 
E.О. Беликова. Толерантность как ценность в социокультурном ландшафте региона

раемой опрошенными проблемой. О том, что никаких проблем нет, говорят только 6,6 \% респондентов (рис. 4).

Показательно, что большинство респондентов указывает на нейтральность (49\%) и положительность (44 \%) их опыта общения с представителями других национальностей. Только 7 \% опрошенных указали на то, что характер общения носит отрицательный характер (см. рис. 5).

Женщины чаще мужчин говорят, что характер их общения с представителями дру- гих национальностей носит положительный характер (47,8 \% и $39 \%$, соответственно). Тогда как мужчины чаще женщин указывают на нейтральный характер отношений $(54,3$ \% и 45,6 \%, соответственно).

Отношение к трудовым мигрантам, приезжающим на заработки в Волгоградскую область из стран ближнего зарубежья, более чем у половины опрошенных нейтральное (59,1%). Примерно равные доли респондентов указывают на то, что их отношение положительное $(17,4 \%)$ и отрицательное $(17,5 \%)$ (см. рис. 6$)$.

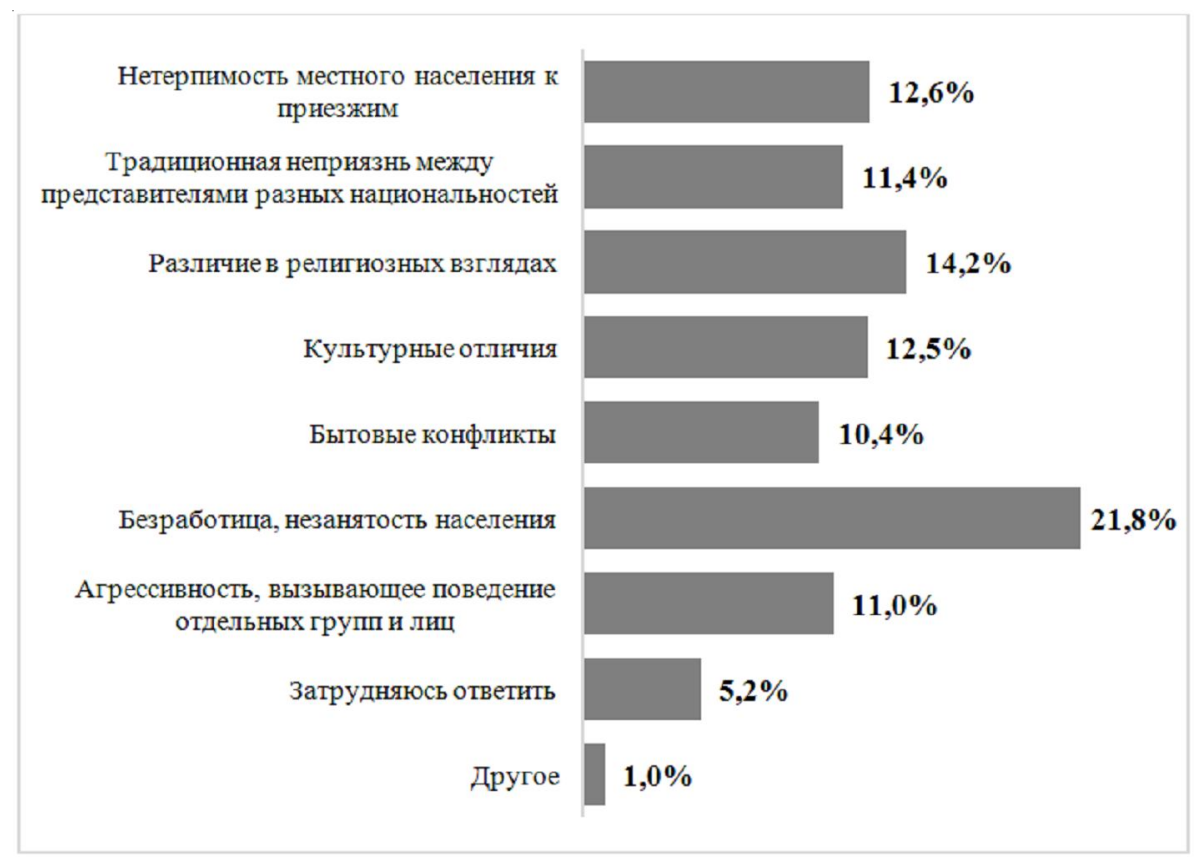

Рис. 3. Основные проблемы, возникающие в сфере межнациональных отношений в Волгоградской области

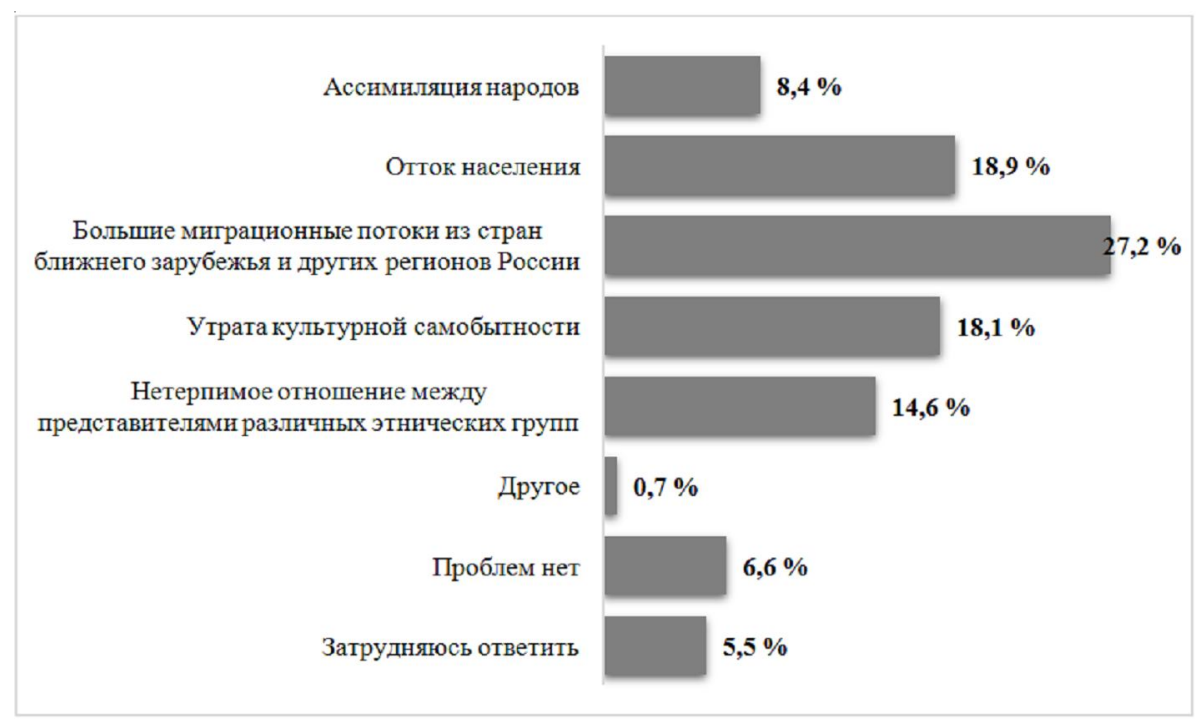

Рис. 4. Актуальные проблемы в этнической сфере 


\section{СОЦИОЛОГИЯ И СОЦИАЛЬНЫЕ ТЕХНОЛОГИИ}

Женщины чаще мужчин говорят, что в целом положительно относятся к трудовым мигрантам, приезжающим на заработки в Волгоградскую область из стран ближнего зарубежья (19,5\% и 14,9\%, соответственно). Мужчины обычно демонстрируют нейтральное отношение.

Превалирующее количество опрошенных считает, что отношения между местными жителями и иностранными гражданами в их населенных пунктах складываются положительно $(62,7 \%)$, на обратную ситуацию указывают $17,1 \%$ респондентов.

Значимым результатом исследования, свидетельствующим о достаточно высокой толерантности респондентов, является то, что подавляющее число опрошенных (77 \%) утверждает, что у них нет неприязни, раздражения по отношению к представителям каких-либо национальностей. Отметили, что чувство неприязни и раздражения у них вызывают народы Северного Кавказа и Закавказья, 16,8 \% респондентов. Народы Средней Азии вызывают негативные чувства у $3,3 \%$ опрошенных (см. рис. 7).

Респонденты из Волгограда чаще говорят, что на укрепление межнациональных отношений влияют соблюдение равенства прав людей разных национальностей $(19,2$ \%) и изучение приезжими русского языка и культуры $(18,3 \%)$. По мнению четверти опрошенных $(26,2$ \%), на гармонизацию межнациональных отношений в случае возникновения острого конфликта на национальной почве в Волгоградской области смогут повлиять правоохранительные органы; 20,1 \% респондентов считают, что на гармонизацию окажут влияние

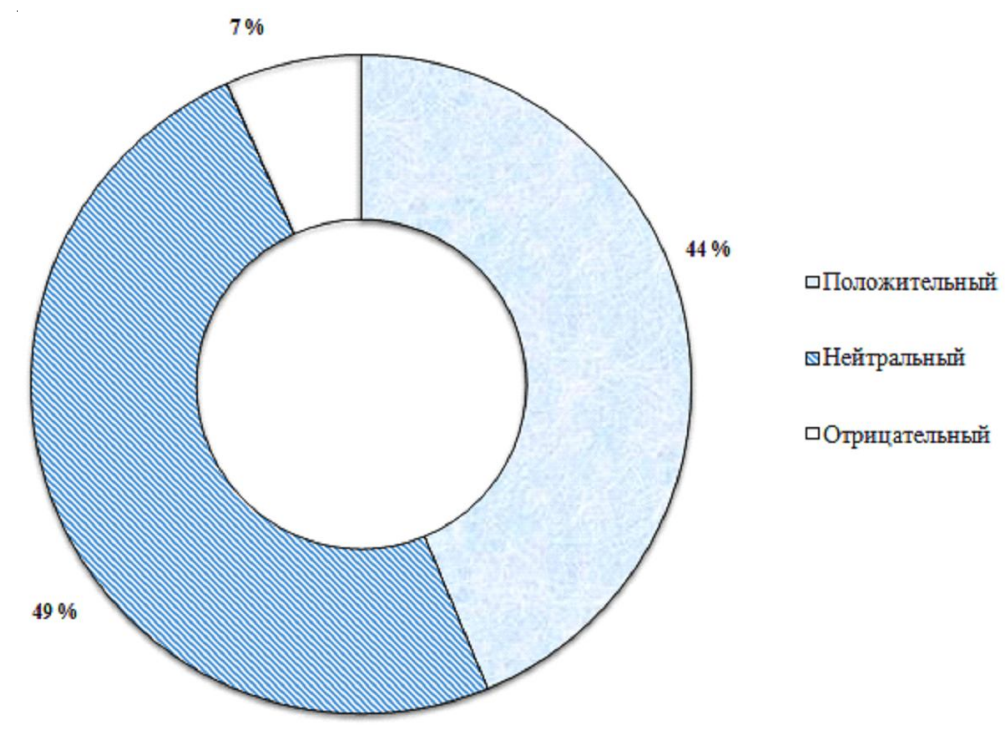

Рис. 5. Характер общения с представителями других национальностей

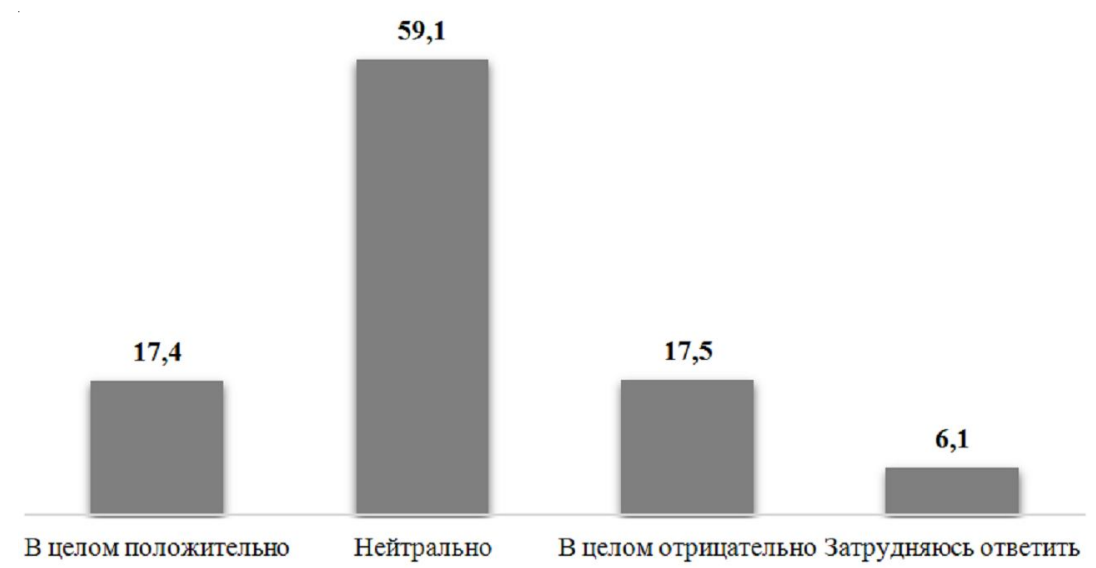

Рис. 6. Отношение к трудовым мигрантам, приезжающим на заработки в Волгоградскую область из стран ближнего зарубежья, в \% 
E.О. Беликова. Толерантность как ценность в социокультурном ландшафте региона

представители диаспор, а 17,5 \%, что органы местного самоуправления (рис. 8).

Наиболее удобным источником получения информации о состоянии дел в сфере межнациональных отношений в Волгоградской области для респондентов является телевидение $(41,5 \%) ; 13,1 \%$ отмечают в качестве удобных источников информации социальные сети, и 12 \% - информационные интернет-порталы. Реже всего респонденты называют удобными официальные сайты органов местного самоуправления $(2,2 \%)$ и неформальные источники информации (4,3\%) (см. рис. 9).
Вероятность проявления радикальных, экстремистских идей на телевидении незначительно большее число опрошенных оценивает как низкую (31,8 \%). Тем не менее $30 \%$ респондентов говорит о высокой вероятности. Опрошенные жители низко оценивают вероятность проявления радикальных, экстремистских идей в прессе $(36,7 \%)$ и на радио $(43,5 \%)$, в социальных сетях скорее как среднюю - 29,6 \%. На информационных интернет-порталах практически в равных долях: как высокую $(27,4$ \%) и как низкую $(28,1 \%)$.

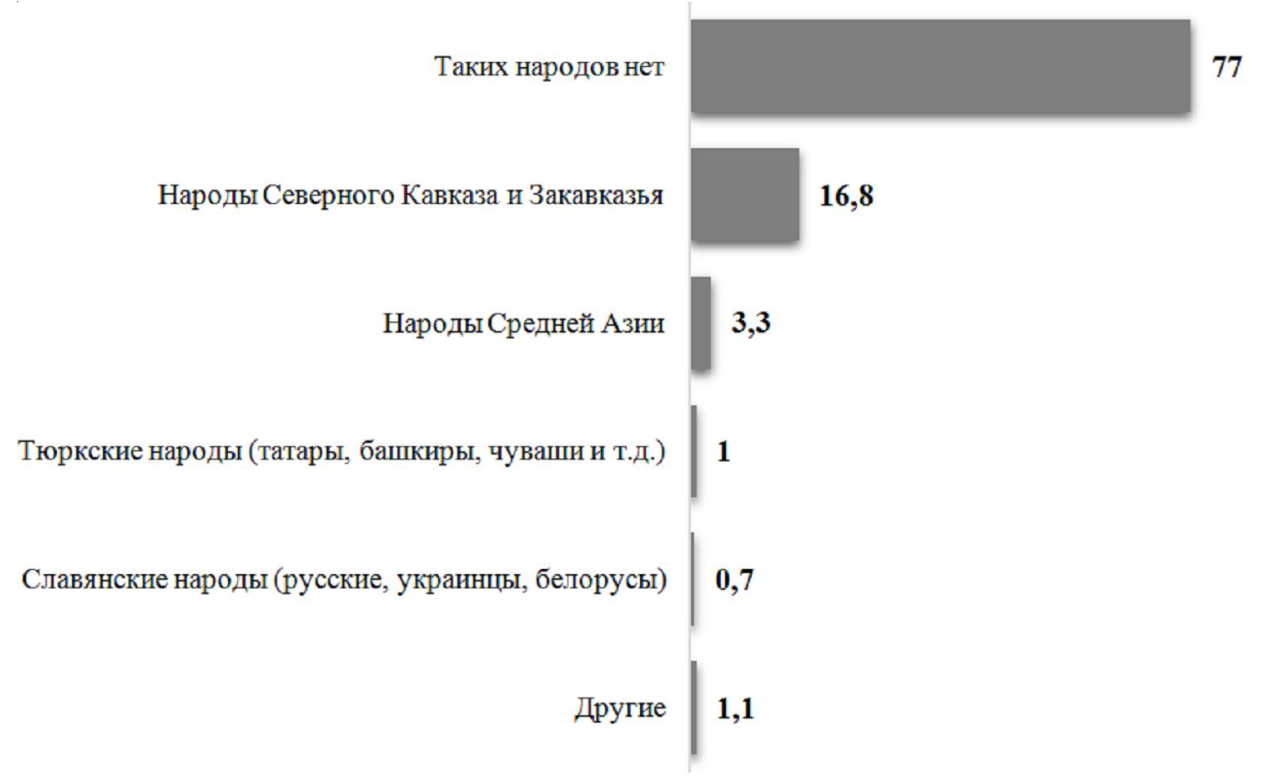

Рис. 7. Национальности, вызывающие чувство неприязни, раздражения, в \%

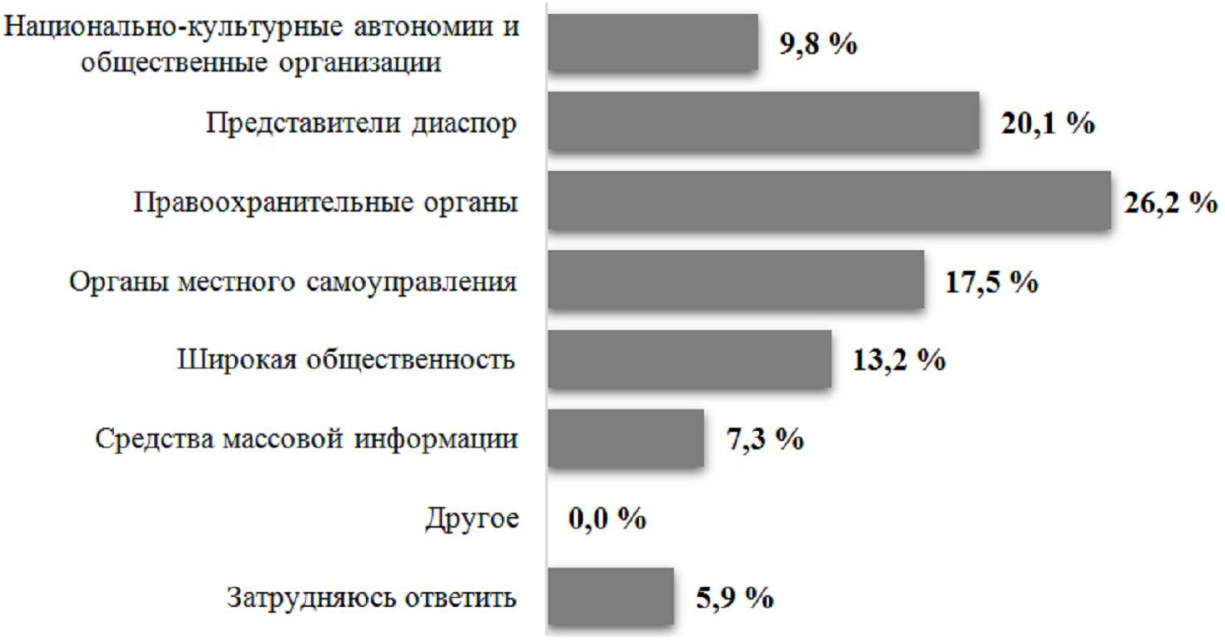

Рис. 8. Структуры, способные повилять на гармонизацию межнациональных отношений в случае возникновения острого конфликта на национальной почве в Волгоградской области 


\section{СОЦИОЛОГИЯ И СОЦИАЛЬНЫЕ ТЕХНОЛОГИИ}

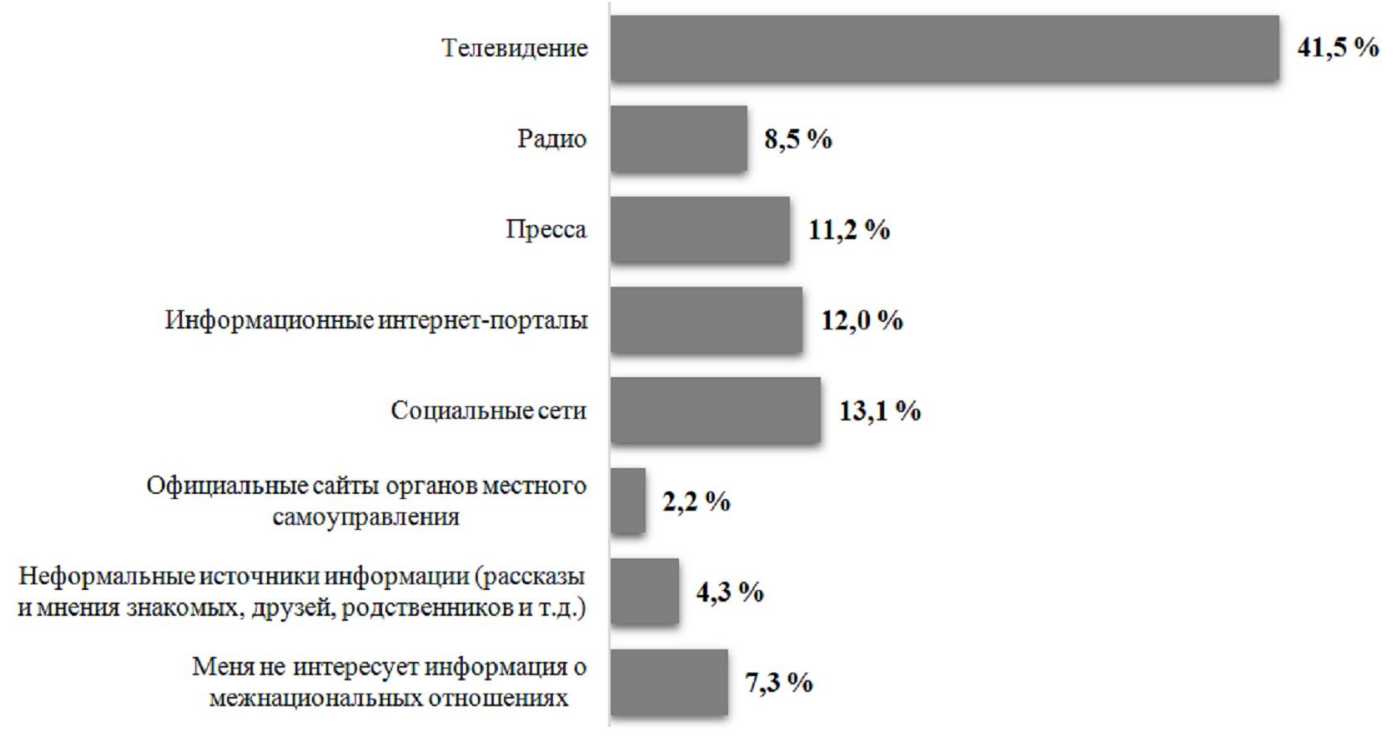

Рис. 9. Наиболее удобные источники получения информации о состоянии дел в сфере межнациональных отношений в Волгоградской области

\section{Выводы}

По результатам проведенного исследования можно сделать вывод о благоприятной обстановке и ситуации в сфере межнациональных отношений на территории Волгоградской области. В настоящее время сфера межнациональной толерантности имеет стабильный характер, критические и острые проблемы отсутствуют.

В целом большинство опрошенного населения оценивает состояние межнациональных отношений в области как нейтральное и благоприятное. О возможности конфликтов на этой почве высказывается минимальное число респондентов. Говоря о динамике изменений обстановки в сфере межнациональных отношений за последние 3 года, отметим, что по результатам анализа респонденты в большинстве склонны утверждать, что она не изменилась. Тем не менее фиксируется, что об ухудшении обстановки говорят чуть большие доли населения, чем об улучшениях в данной сфере.

Среди основных проблем, возникающих в сфере межнациональных отношений в Волгоградской области, можно выделить следующие:

- безработица, незанятость населения;

- культурные различия;

- различия в религиозных взглядах;

- бытовые конфликты.
Наиболее актуальными проблемами в этнической сфере респонденты чаще всего считают:

- большие миграционные потоки из стран ближнего зарубежья и других регионов России;

- отток населения;

- утрата национальной самобытности.

Рассматривая опыт общения респондентов с представителями других национальностей, скажем, что превалирующее большинство отмечает нейтральный или положительный характер подобного опыта. Значимым является и тот факт, что большинство респондентов не испытывает чувства неприязни, раздражения к представителям каких-либо национальностей. Только каждый 6-й опрошенный испытывает чувство неприязни к представителям народов Северного Кавказа и Закавказья и каждый 12-й - к представителям народов Средней Азии.

Отношение опрошенных жителей к трудовым мигрантам, приезжающим на заработки в Волгоградскую область из стран ближнего зарубежья, как правило, можно охарактеризовать как нейтральное, без явного положительного или негативного оттенка. В ходе анализа выявлено, что чаще других высказывают отрицательное отношение к трудовым мигрантам, приезжающим на заработки в Волгоградскую область из стран ближнего 
зарубежья, опрошенные жители Быковского и Урюпинского районов.

Результаты опроса показали, что на укрепление межнациональных отношений в Волгоградской области в первую очередь могут повлиять:

- знакомство людей с культурой других национальностей с помощью совместных культурных мероприятий, праздников;

- совместное обучение детей разных национальностей в учебных заведениях;

- соблюдение равенства прав людей разных национальностей;

- ограничение въезда мигрантов.

Говоря о структурах, которые в случае возникновения конфликта на национальной почве в Волгоградской области могут повлиять на гармонизацию межнациональных отношений, прежде всего выделим:

- правоохранительные органы;

- органы местного самоуправления;

- представители диаспор;

- широкая общественность.

Наиболее удобными каналами получения информации о состоянии дел в сфере межнациональных отношений в Волгоградской области для населения в ходе опроса стали телевидение и социальные сети. Вероятность проявления радикальных, экстремистских идей в средствах массовой информации, по результатам опроса, оценивается на среднем уровне как в прессе, на радио, на информационных интернет-порталах, так и в социальных сетях. Лишь на телевидении вероятность проявления радикальных, экстремистских идей оценивается респондентами как высокая.

Однако прослеживается необходимость в проведении регулярных мониторингов общественных настроений с целью выявления конкретных проблем и выработки мер по их разрешению и недопущению повышения уровня межнациональной напряженности.

\section{ПРИМЕЧАНИЕ}

${ }^{1}$ Исследование выполнено при финансовой поддержке РФФИ в рамках научного проекта № 18-411-340011 p_a «Сохранение и трансляция региональных ценностей как условие модернизации социокультурного ландшафта современного российского региона».

The reported study was funded by RFBR according to the research project no. 18-411-340011 p_a "Preservation and translation of regional values as a condition for the modernization of the sociocultural landscape of the modern Russian region".

\section{СПИСОК ЛИТЕРАТУРЫ}

Беликова 2016 - Беликова Е.О. Стратегия развития межнациональных и межкультурных взаимодействий в Волгоградской области // Научный вестник Волгоградского филиала РАНХиГС. Серия: Социология и политология. 2016. № 1. C. 40-43.

Богатова, Карьгин 2010 - Богатова О.А., Карьгин А.И. Мониторинг межэтнических и межконфессиональных отношений в Республике Мордовия // Финно-угорский мир. 2010. № 1. C. 78-91.

Васильева (ред.) 2011 - Васильева А.Б. (ред.). Философский энциклопедический словарь. 2-е изд. М.: Инфра-М, 2011.

Зиннатова 2017 - Зиннатова А.А. Социокультурный контекст толерантности в аспекте реализации механизмов нового социокультурного пространства // Вестник КазГУКИ. 2017. № 2. C. $51-55$.

Кустова, Меркулов, Арабаджийски 2018 - Кустова А.В., Меркулов П.А., Арабаджийски Н.3. Социальная толерантность: российский и зарубежный опыт // Среднерусский вестник общественных наук. 2018. Т. 13, № 1. С. 79-93.

Качур 2019 - Качур С.A. Особенности межконфессиональных отношений в приграничных регионах Российской Федерации: обзор прикладных и теоретических исследований // Society and Security Insights. 2019. T. 2, № 4. C. 126-137.

Лапин 2009 - Лапин Н.И. Социокультурный подход к изучению эволюции России и ее регионов // Регионы в России: социокультурные портреты регионов в общероссийском контексте. М.: Academia, 2009.

Лебедева, Таболина, Гаюрова 2002 - Лебедева Н.М., Таболина Т.В., Гаюрова Ю.А. Этническая толерантность в поликультурных регионах России. М.: Изд-во Рос. ун-та дружбы народов, 2002.

Локк 1988 - Локк Дж. Послание о веротерпимости // Сочинения в 3 т. Т. 3. М.: Мысль, 1988.

Неровная, 2018 - Неровная Н.А. Содержание концепта «толерантность» в английском языковом сознании: динамический аспект // Вест- 
ник Волгоградского государственного университета. Серия 2, Языкознание. 2018. Т. 17, № 2. C. 126-133. DOI: https://doi.org/10.15688/ jvolsu2.2018.2.14.

Рыжова 2016 - Рыжжова С.В. Доверие и межэтническая толерантность. Исследование в Москве и регионах России // Этносоциология вчера и сегодня. М.: Ин-т этнологии и антропологии РАН, 2016.

Hawa 2017 - Hawa S. Erasure of Arab Political Identity, Colonialism and Violence. Milton Park, Abingdon, Oxon: Routledge, 2017.

Kruiniger 2015 - Kruiniger P. Islamic Divorces in Europe: Bridging the Gap Between European and Islamic Legal Orders. Hague: Eleven International Publishing, 2015.

Kupiszewski 2013 - Kupiszewski M. International Migration and the Future of Populations and Labour Force Resources in Europe. Dordrecht: Springer, 2013.

\section{REFERENCES}

Belikova E.O., 2016. Strategiya razvitiya mezhnatsionalnykh i mezhkulturnykh vzaimodeystviy v Volgogradskoy oblasti. Nauchnyy vestnik Volgogradskogo filiala RANKhiGS. Seriya: Sotsiologiya i politologiya, no. 1, pp. 40-43.

Bogatova O.A., Kar'gin A.I., 2010. Monitoring mezhetnicheskikh i mezhkonfessionalnykh otnosheniy v Respublike Mordoviya. Finnougorskiy mir, no. 1, pp. 78-91.

Vasil'yeva A.B. (ed.), 2011. Filosofskiy entsiklopedicheskiy slovar. Moscow, Infra-M Publ.

Zinnatova A.A., 2017. Sotsiokulturnyy kontekst tolerantnosti $\mathrm{v}$ aspekte realizatsii mekhanizmov novogo sotsiokulturnogo prostranstva. Vestnik KazGUKI, no. 2, pp. 51-55.

Kustova A.V., Merkulov P.A., Arabadzhiyski N.Z., 2018. Sotsialnaya tolerantnost: rossiyskiy i zarubezhnyy opyt. Srednerusskiy vestnik obshchestvennykh nauk, vol. 13, no. 1, pp. 79-93.

Kachur S.A., $2019 . \quad$ Osobennosti mezhkonfessionalnykh otnosheniy V prigranichnykh regionakh Rossiyskoy Federatsii: obzor prikladnykh i teoreticheskikh issledovaniy. Society and Security Insights, vol. 2 , no. 4, pp. 126-137.

Lapin N.I., 2009. Sotsiokulturnyy podkhod k izucheniyu evolyutsii Rossii i yeyo regionov. Regiony v Rossii: sotsiokulturnyye portrety regionov $v$ obshcherossiyskom kontekste. Moscow, Academia.

Lebedeva N.M., Tabolina T.V., Gayurova Yu.A., 2002. Etnicheskaya tolerantnost $v$ polikulturnykh regionakh Rossii. Moscow, Izd-vo Ros. un-ta druzhby narodov.

Lokk Dzh., 1988. Poslaniye o veroterpimosti. Compositions in 4 vols. Vol. 4. Moscow, URSS Publ.

Nerovnaya N.A., 2018. Soderzhaniye kontsepta «tolerantnost» $\mathrm{v}$ angliyskom yazykovom soznanii: dinamicheskiy aspect. Vestnik Volgogradskogo gosudarstvennogo universiteta. Seriya 2, Yazykoznaniye, vol. 17, no. 2, pp. 126-133. DOI: https://doi.org/10.15688/jvolsu2.2018.2.14.

Ryzhova S.V., 2016. Doveriye i mezhetnicheskaya tolerantnost. Issledovaniye v Moskve i regionakh Rossii. Etnosotsiologiya vchera $i$ segodnya. Moscow, Institut etnologii i antropologii RAN.

Hawa S., 2017. Erasure of Arab Political Identity, Colonialism and Violence. Milton Park, Abingdon, Oxon, Routledge.

Kruiniger P., 2015. Islamic Divorces in Europe: Bridging the Gap Between European and Islamic Legal Orders. Hague, Eleven International Publishing.

Kupiszewski M., 2013. International Migration and the Future of Populations and Labour Force Resources in Europe. Dordrecht, Springer.

\section{Information About the Author}

Ekaterina O. Belikova, Candidate of Sciences (Sociology), Associate Professor, Department of Sociology and Social Technology, Volgograd State University, Prosp. Universitetsky, 100, 400062 Volgograd, Russian Federation, eo_belikova@volsu.ru, https://orcid.org/0000-0002-8686-1770

\section{Информация об авторе}

Екатерина Олеговна Беликова, кандидат социологических наук, доцент кафедры социологии и социальных технологий, Волгоградский государственный университет, просп. Университетский, 100, 400062 г. Волгоград, Российская Федерация, eo_belikova@volsu.ru, https://orcid.org/0000-0002-8686-1770 